\title{
PENGARUH RENDAMAN AIR TERHADAP KUALITAS DNA PADA SPERMA DENGAN STR-CODIS D13S317 DAN D21S1
}

\author{
Abdul Hadi Furqoni ${ }^{* 1}$, Ahmad Yudianto ${ }^{2}$, Puspa Wardhani ${ }^{3}$ \\ Sekolah Pascasarjana Universitas Airlangga; Kampus B. Jl. Airlangga No. 4-6, Surabaya \\ 60286, Telp. (031) 5041566 / Fax. (031) 5029856 \\ Program Studi S2 Ilmu Forensik \\ e-mail : ${ }^{* 1}$ cocohadi01@gmail.com, yudi4n6@yahoo.co.id ${ }^{2}$, puspa pk@yahoo.co.id ${ }^{3}$
}

\begin{abstract}
Abstrak
Kriminalitas yang terjadi akibat kejahatan seksual banyak terjadi di mana-mana. Kejahatan ini bisa menimpa beberapa orang dan dari berbagai umur. Dalam kasus ini pasti akan di temukan barang bukti di tempat kejadian perkara. Salah satu bukti akibat kejahatan seksual adalah bercak sperma. Bercak sperma dapat di temukan seperti pada pakaian yang digunakan korban atau pelaku. Dengan keterbatasan waktu yang dimiliki oleh polisi tentunya perlu cara untuk pengidentifikasi siapa pelaku dari kejahatan tersebut. Sampel bercak sperma akan di isolasi DNA. Isolasi DNA adalah memisahkan DNA yang ada pada sel sperma dengan komponen yang lainnya. Setelah DNA di dapatkan akan di ketahui kadar dan kemurniannya. Hasil tersebut bisa di pengaruhi oleh media bercak sperma berada. Faktorfaktor tersebut salah satunya media air dan kain katun. Sifat kain katun adalah mempunyai kemampuan menyerap yang tinggi walaupun dalam keadaan basah sekalipun. Setelah isolasi DNA, tahapan selanjutnya adalah amplifikasi. Proses amplifikasi dalam penelitian ini adalah menggunakaan STR dengan lokus D13S317 dan D21S11.
\end{abstract}

Kata kunci : Kriminal, Sperma, DNA, STR-CODIS

\begin{abstract}
Case of crimes due to sexual crimes happen frequently and everywhere. This type of crime may happen to a number of people and from different range of age. In this case, there must be evidence in the crime scene. One of the evidences of sexual crime is sperm stain. Sperm stain may be found such as on a clothing worn by the victims or criminals. Due to the limitation of time that the police has, a method to identify who the real culprit of such crime is needed. Sperm stain sample will be brought to the lab for DNA isolation. DNA isolation means separating DNA in the sperm cell from the other components. After the DNA is obtained, the concentration and purity will be identified. The result may be affected by the media where the sperm is staining. One of the factors is water and cotton cloth media. The feature of cotton cloth is that it is highly absorbent even though it is in wet condition. After DNA isolation, the next step is amplification. Amplification process in this research is using STR with D13S317 and D21S11 loci.
\end{abstract}

Keywords : Crime, sperm, DNA, STR-CODIS 


\section{PENDAHULUAN}

Pada zaman modern seperti sekarang, banyak ditemukan tindakan melanggar hukum (kriminalitas) di berbagai belahan dunia, terutama di negara miskin dan negara berkembang seperti Indonesia. Kriminalitas dapat berupa pembunuhan, terorisme, pencurian, pemerkosaan dan sebagaiya. Dalam Dunia Internasional, Indonesia menduduki peringkat ke 62, dengan jumlah 0,00567 per 1000 orang atau 5-6 per satu juta orang dalam kasus pemerkosaan. Apabila jumlah penduduk Indonesia sebanyak 250 juta jiwa, maka ada 1418 kasus pemerkosaan yang terjadi. Untuk ukuran Nasional, Provinsi Bandar Lampung merupakan Provinsi dengan kasus pemerkosaan tertinggi. Pada tahun 2009 telah terjadi 106 kasus pemerkosaan di Bandar Lampung, diikuti oleh Jakarta sebanyak 90 kasus. Sedangkan Provinsi Bali hanya terjadi 19 kasus pemerkosaan (Yulia, 2010). Sekian banyak kasus pemerkosaan yang terjadi, selalu ditemukan masalah yang sulit untuk di selesaikan olek pihak berwajib. Tentunya untuk mengolah TKP pun ada batas waktu untuk menilai kemurnian dari setiap tandatanda yang ditemukan pada tempat kejadian.

Pada Perkap nomor 10 tahun 2009 khususnya terkait tata cara dan persyaratan permintaan Pemeriksaan Teknis Kriminalistik TKP pasal 6 ayat 1 huruf $B$ menyatakan "dalam hal tertentu dan keadaan mendesak permintaan pemeriksaan dapat diajukan secara lisan atau melalui telepon, dan permintaan tertulis harus sudah disusulkan paling lama 7 (tujuh) hari kerja setelah pemeriksaan TKP dilaksanakan". Terbatasnya waktu yang diberikan untuk bisa mengolah TKP, diharapkan pihak berwajib bisa memaksimalkan tugasnya dalam menemukan tanda-tanda yang dapat mengungkap kasus yang terjadi. Pada kasus pemerkosaan sering ditemukan barang bukti sebagai contoh sperma, baik di bagian tubuh korban, terutama vagina atau di media seperti pada kondom atau pakaian korban yang ada di TKP (tempat kejadian perkara).

Sperma adalah sel reproduksi dari tubuh jantan, yang diteliti pertama kali pada tahun 1677 oleh Stephen Ham, salah satu murid dari
Antonie van Leeuwenhoek (Adnan, 2006). Semua sel maupun jaringan makhluk hidup termasuk spermatozoa yang terdapat pada sperma mengandung (Deoxyribonucleic acid) DNA (Robert, 2007). Sperma sering digunakan sebagai bukti untuk menyelesaikan kasus pemerkosaan, terutama dalam identifikasi pelaku.

Sampel dari cairan ejakulat berupa bercak sperma yang terdapat pada baju/kain di TKP ataupun cairan/swab vagina dapat dipengaruhi oleh faktor-faktor luar yang dapat menurunkan kualitas DNA nya. Contoh faktornya seperti suhu, kelembapan, cahaya, media sperti sperma yang terdapat pada kain, rendaman air tawar, dll. Penelitian yang dilakukan oleh Wahyuningsih (2008) tentang kain katun, disimpulkan bahwa kain katun mempunyai sifat tidak kuat terhadap asam berat dan apabila di rendam pada air yang memiliki kadar asam tinggi akan merusak komponen dari kain itu sendiri. Pada penelitian yang dilakukan oleh Nursida (2011) terdapat hasil bahwa jumlah rata - rata fragmen DNA hasil amplifikasi Ikan kerapu pada toleran salinitas rendah lebih besar dibandingkan daripada ikan yang toleran salinitas tinggi.

Dalam mengungkap tersangka dalam kasus pemerkosaan, bisa dilakukan dengan cara mengidentifikasi DNA yang terdapat pada bercak sperma yang ditemukan. Dalam pelaksanaannya diperlukan primer seperti (Short tandem repeat combined DNA index) STR-CODIS untuk mengamplifikasi DNA yang sangat sedikit. STR adalah bagian DNA yang pendek dan bersifat polimorfik yang paling informatif berdasarkan PCR untuk mencoba untuk mengindividualisasi bahan biologis. STR-CODIS sering di pakai pada kasus untuk identifikasi pada manusia di karenakan sudah di sepakati oleh lembaga forensik dunia dan FBI sebagai cara yang mudah untuk mencocokkan sampel yang ada di TKP dengan sampel terduga korban atau tersangka (Butler, 2006).

Berdasarkan latar belakang diatas maka pada tesis ini akan membahas pengaruh paparan rendaman air tawar dalam waktu yang berbeda terhadap kualitas DNA pada bercak sperma yang dideteksi dengan STR-CODIS D13S317 dan D21S11. 


\section{TINJAUAN PUSTAKA}

\subsection{Deoxyribo Nucleic Acid (DNA)}

Sel merupakan unit struktural dan fungsional dari organisme yang ditemukan pertama kali oleh peneliti Inggris bernama Robert Hooke. Sel eukariot jauh lebih kompleks daripada sel prokariot, karena sel eukariot memiliki membran dan organel tertentu yang tidak dimiliki sel prokariot. Di dalam sebuah sel juga erdapat materi genetik, tepatnya terletak pada inti sel dan mitokondria pada hewan atau kloroplast pada tumbuhan. Materi genetik dapat berupa Deoxyribo Nucleic Acid (DNA) atau Ribonucleic Acid (RNA) (Campbell et all, 2004).

Deoxyribo Nucleic Acid (DNA) adalah asam nukleat yang membawa informasi genetik dari generasi ke generasi selanjutnya. DNA terdapat pada nukleus, mitokondriapada hewan dan terdapat juga pada kloroplas tumbuhan. Ada beberapa perbedaan antara DNA tersebut, yaitu: DNA nukleus yang disebut juga DNA kromosomal, berbentuk benang lurus (linear) tak bercabang dan berasosiasi sangat erat dengan protein histon, sedangkan DNA mitokondria dan kloroplas berbentuk melingkar (sirkular) dan tidak berasosiasi dengan protein histon.

DNA mitokondria dan kloroplas memiliki cirri khas, yaitu hanya mewariskan sifat-sifat yang berasal dari ibu, sedangkan DNA nukleus memiliki pola pewarisan sifat dari kedua orang tuanya (Raven dan Johnson, 2002). Ukuran molekul DNA setiap spesies berbeda satu dengan yang lainnya. Pada mitokondria berukuran $5 \mu$, molekul DNA bakteri berukuran 1,4 mm, sedangkan molekul DNA pada Riggs (Suryo, 2005). Menurut Watson dan Crick dalm Suryo (2005), molekul DNA berbentuk double helix. DNA terdiri atas susunankimia yang terdiri atas tiga macam molekul yaitu : yaitu gula pentose yang dikenal sebagai deoksirobisa, asam fosfat, dan basa nitrogen yang terdiri atas basa purin dan pirimidin.
Menurut Lewis (2003) purin terdiri atas adenin (A) dan guanin $(\mathrm{G})$, sedangkan pirimidin dibedakan menjadi timin (T) dan sitosin (S). Adenin hanya akan berpasangan dengan timin dan guanin hanya berpasangan dengan sitosin. Adenin dan timin dihubungan oleh dua atom hidrogen, sedangkan guanin dan sitosin dihubungkan dengan tiga atom hidrogen.

Molekul DNA dari mahluk hidup diperoleh dengan cara melakukan ekstraksi DNA dari seluruh bagian biologis mahluk hidup tersebut, salah satunya adalah spermatozoa. Ekstraksi DNA memiliki beberapa metode seperti medote fenol klorofom, metode membran dialisis, metode chilex (Toha, 2001). DNA yang bisa didapatkan dari proses ekstraksi relatif sedikit, maka dari itu untuk kepentingan analisis perlu dilakukan perbanyakan DNA. Proses perbanyakan DNA itu disebut dengan amplifikasi DNA. Proses perbanyakan ini dilakukan melalui suatu rangkaian reaksi yang di sebut dengan Polymerase Chain Reaction (PCR) (Son 2007).

\subsection{Sperma}

Sperma adalah sel reproduksi dari tubuh jantan, yang diteliti pertama kali pada tahun 1677 oleh salah satu murid dari Antonie Van Leeuwenhoek. Sperma diproduksi melalui proses spermatogenesis yang terjadi didalam tubulus seminiferus pada testis. Spermatogenesis terdiri atas tiga tahapan, yaitu berlangsung pada suhu $35^{\circ}$ - $36^{\circ}$. Apabila suhu tidak sesuai maka proses spermatogenesis tidak akan berjalan secara optimal, yang akan berpengaruh pada jumlah dan bentuk sperma yang dihasilkan. Selain suhu, proses spermatogenesis juga dipengaruhi oleh senyawa kimia, dan lain-lain (Johnson, 2003).

Spermatogenesis atau proses pembentukan sperma, terjadi di dalam testis, tepatnya terjadi di tubulus seminiferus. Spermatogenesis terjadi setelah seorang laki-laki mengalami masa puber (dewasa secara fisiologis). 
Spermatogenesis kemudian akan terjadi secara teratur dan terus menerus seumur hidup laki-laki.

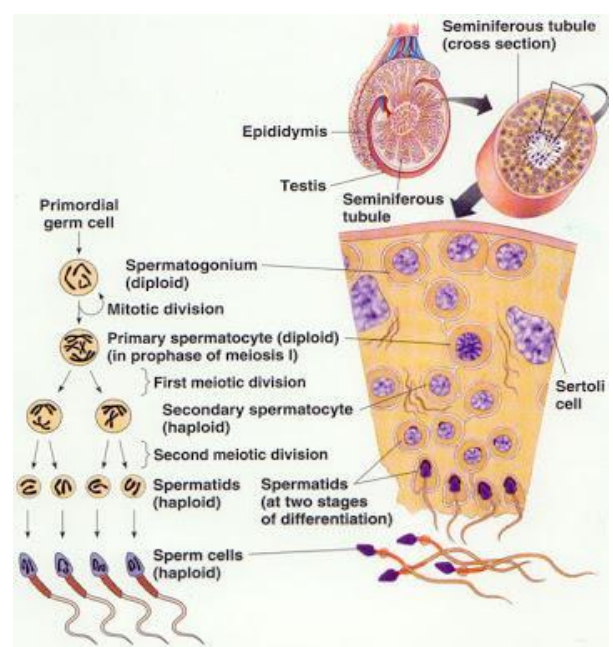

Gambar 1. Tahapan Spermatogenesis (Suryo,2005)

\subsubsection{Tahapan Perkembangan Sel Kecambah}

Tubulus seminiferus yang ada pada testes pria, terdiri dari sel-sel diploid yang dinamakan spermatogonia yang akan berkembang menjadi sperma yang matang. Proses yang terjadi yaitu adanya peralihan proses pembelahan serta perubahan struktur yang fungsional melalui proses pembelahan serta perubahan struktur secara berurutan. Secara umum tahap perkembangan sel germa hingga menjadi spermatozoa meliputi:

1. Spermatogonium, biasanya terletak di tepi tubulus seminiferus.

2. Spermatosit primer.

3. Spermatosit sekunder.

4. Spermatid, berukuran relatif kecil dan mempunyai bakal tudung di bagian ujung inti.

5. Spermatozoa, sudah memiliki bagian kepala serta ekor.

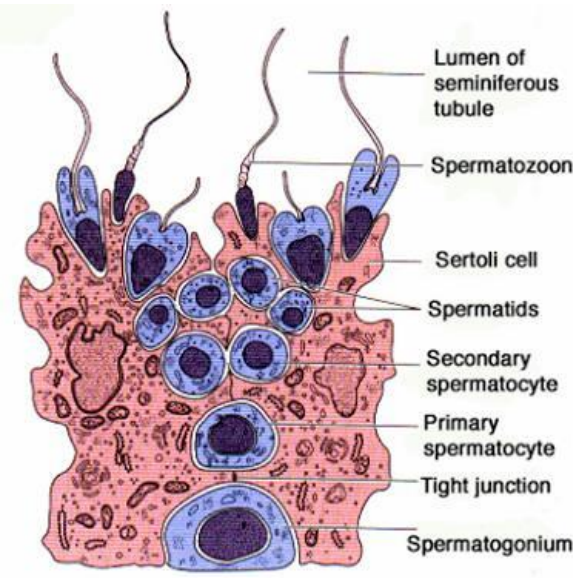

Gambar 2. Tahapan Perkembangan Sel Kecambah (Suryo, 2005)

\subsubsection{Struktur Sperma}

Setelah terbentuk sempurna, spermatozoa masuk ke dalam rongga tubulus seminiferus, kemudian akibat kontraksi dinding tubulus spermatozoa terdorong ke arah epididimis. Suasana keseimbangan asam-basa dan elektrolit yang sesuai di intratubulus dan epididimis memberikan spermatozoa kemampuan untuk bergerak (motilitas sperma) (Suryo, 2005). Sperma diproduksi sebanyak 300 juta per hari. Rata-rata volume air mani untuk setiap ejakulasi adalah 2,5 sampai $6 \mathrm{ml}$, dan rata-rata jumlah sperma yang diejakulasikan adalah 40-100 juta per $\mathrm{ml}$ (Suryo, 2005). Ukuran sperma dewasa yaitu $60 \mu \mathrm{m} . v$ Spermatozoa masak terdiri dari :

1. Kepala (head, caput), terdiri dari sel berinti tebal dengan hanya sedikit sitoplasma, mengandung inti (nukleus) dengan kromosom dan bahan genetiknya. Pada bagian membran permukaan di ujung kepala sperma terdapat selubung tebal yang disebut akrosom. Akrosom mengandung enzim hialuronidase dan proteinase yang berfungsi untuk menembus lapisan pelindung ovum. Ukuran kepala sperma sendiri yaitu panjang $5 \mu \mathrm{m}$ dan lebar $3 \mu \mathrm{m}$. bagian posterior 
membran inti membentuk basal plate.

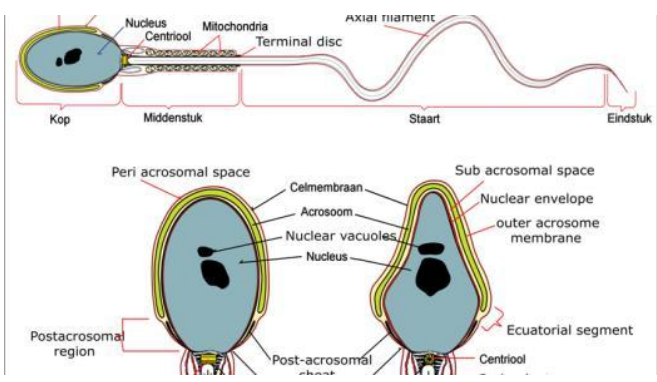

Gambar 3. Struktur Kepala Sperma (Suryo, 2005)

2. Leher (neck, cervix), menghubungkan kepala dengan badan. Terdiri dari sembilan segmen kolom materi berserat, berlanjut sebagai serat padat terluar ekor.

3. Badan (middle piece, corpus), panjangnya $5 \mu \mathrm{m}$, banyak mengandung mitokondria yang berfungsi sebagai penghasil energi untuk pergerakan sperma.

4. Ekor (tail, caudal), panjangnya $45 \mu \mathrm{m}$, berfungsi untuk mendorong spermatozoa masak ke dalam vas deferen dan ductus ejakulotoris.

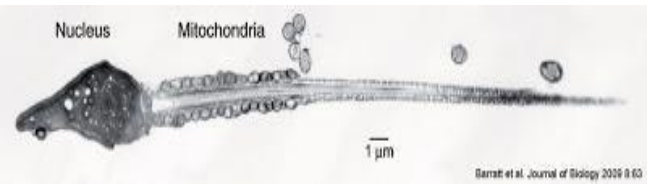

Gambar 4. Struktur Sperma Manusia dengan Mikroskop Elektron (Suryo, 2005)

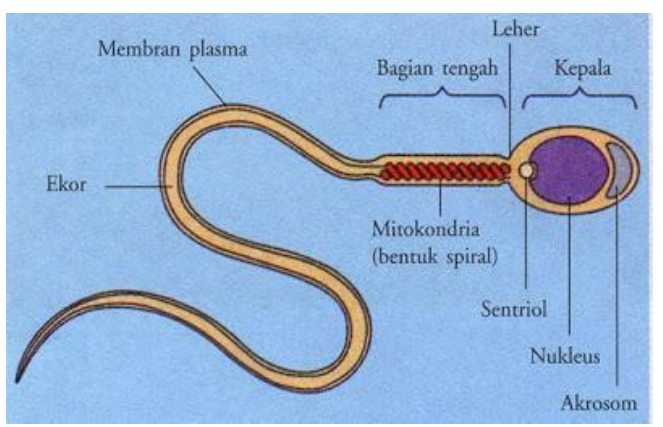

Gambar 5. Gambar Struktur Sperma Manusia (Suryo, 2005)

Menurut Suryo (2005) ada dua tipe sperma, yaitu : sperma tipe $\mathrm{X}$ dan sperma tiper $\mathrm{Y}$. Sperma tipe $\mathrm{X}$ adalah sperma yang membawa 22 kromosom tubuh dan kromosom kelamin $\mathrm{X}$ yang menentukan jenis kelamin perempuan. Sperma tipe $\mathrm{Y}$ adalah sperma yang membawa 22 kromosom tubuh dan kromosom kelamin Y yang menentukan jenis kelamin laki-laki saat fertilisasi. Sperma tipe $\mathrm{X}$ akan bergerak dengan cepat dalam kondisi lingkungan yang asam, sedangkan sperma tipe $\mathrm{Y}$ akan bergerak dengan cepat dalam kondisi basa.

\subsubsection{Struktur DNA dan Kromatin Spermatozoa}

Berbeda dengan sel somatik, spermatozoa manusia memiliki struktur dan integritas fungsional yang dikemas dalam sistem yang unik. Materi DNA spermatozoa manusia dikemas dengan bantuan protein khusus yang mengatur proses kondensasi dan dekompresi melalui mekanisme tertentu. Keseimbangan proses itu disinkronisasi oleh struktur organisasi DNA spermatozoa (Singh, 2011). Secara struktural, sebagian besar DNA spermatozoa melingkar menjadi toroid, sebagian kecil berikatan dengan histon dan sisanya melekat di matriks inti spermatozoa matrix attachment regions (MARs).

Organisasi DNA spermatozoa yang paling padat berada di dalam toroid. Selama proses maturasi, sebagian besar protein histon yang berasosiasi dengan DNA digantikan oleh protamin (Gambar 2). Adanya protamin yang berikatan dengan DNA, memungkinkan terjadi proses kondensasi yang lebih erat dan membuat DNA resisten terhadap nuclease (Singh, 2011). Untuk memperoleh struktur DNA yang padat, proses pengemasan DNA spermatozoa 
juga merupakan mekanisme kontrol ekspresi gen.

Proses tersebut menahan akses ke reading frame dan menyebabkan tidak terjadinya ekspresi gen selama spermatogenesis. Saat spermatozoa fusi dengan oosit protamin akan digantikan seluruhnya dengan protein histon yang disediakan oleh oosit saat empat jam pertama. Penggantian tersebut memberikan kesempatan bagi genom paternal untuk meningkatkan akses dalam memproduksi protein. Oleh karena itu, keseluruhan proses pengemasan DNA/kromatin spermatozoa mengindikasikan fungsi struktur toroid untuk melindungi spermatozoa selama perjalanan dalam saluran reproduksi laki-laki dan perempuan hingga terjadinya fertilisasi dan tidak berperan dalam perkembangan embrio (Singh, 2011).

Protamin terdiri atas pita besar bermuatan positif dan residu arginin yang dinetralkan oleh ikatan fosfodiester DNA. Interaksi tersebut mengurangi repulsion antar ikatan DNA, sehingga memungkinkan DNA berlipat-lipat untuk menciptakan toroid yang kompak dan erat. Toroid berbaris berdampingan untuk menghasilkan luas permukaan maksimal. Protamin tidak hanya memberikan pemadatan struktur DNA, tetapi juga memberikan perlindungan dari kerusakan. Ikatan disulfida antar molekul di kromatin sel spermatozoa lebih resisten terhadap kerusakan mekanik dibandingkan dengan sel somatik (Singh, 2011).

Struktur DNA spermatozoa lainnya adalah DNA yang terikat dengan histon. Histon terutama berikatan di daerah promotor gen. Seluruh famili gen yang vital untuk spermiogenesis dan masa fertilisasi awal secara khusus berasosiasi dengan histon di spermatozoa. DNA yang berikatan dengan histon memberikan akses pada reading frame. Histon DNA spermatozoa tidak digantikan oleh histon pascafertilisasi yang ditemukan dalam oosit. Hal tersebut memungkinkan kerusakan histon DNA spermatozoa ditransmisikan ke embrio tanpa terdeteksi dan termodifikasi. Kejadian tersebut merugikan karena kebanyakan DNA yang terikat di histon adalah kluster gen yang bertanggungjawab terhadap perkembangan awal embrio (Singh, 2011).

Selain DNA spermatozoa yang terikat dengan protamin dan histon bentuk terakhir organisasi spermatozoa adalah matrix attachment region (MAR). MAR merupakan bagian DNA yang melekat di lingkaran domain kromatin matriks inti kaya protein. MAR berukuran tidak lebih dari 1000 pasang basa dan berada di antara toroid protamin yang menempelkan toroid di tempatnya disebut toroid linker. Toroid linker berisi histon dan sangat sensitif terhadap aktivitas nuklease. MAR juga berperan sebagai tempat pemeriksaan integritas DNA spermatozoa setelah fertilisasi. MAR bersama histon terikat DNA lain, langsung berasal dari materi genetik paternal yang diturunkan ke embrio dan penting untuk perkembangan (Singh, 2011).

\subsection{STR - CODIS}

Amplifikasi adalah suatu penerapan bioteknologi untuk memperbanyak DNA pada kromosom. DNA dapat diperbanyak hingga ratusan bahkan ribuan kali. Amplifikasi dapat dilakukan dengan berbagai metode, salah satunya dengan metode PCR (Polymerase Chain Reaction) yang ditemukan Karry Mullis pada tahun 1983. Amplifikasi dengan metode PCR membutuhkan primer. Primer adalah sekuen oligonukleotida (umumnya 10-20 nukleotida) khusus yang akan berikatan dengan DNA pada daerah yang spesifik (Butler, 2006).

Keberhasilan amplifikasi dengan metode PCR dipengaruhi oleh kesesuaian primer dengan bahan ekstraksi dan optimalisasi PCR. Apabila primer tidak 
sesuai dengan bahan ekstraksi akan menyebabkan daerah lain (bukan daerah sasaran) yang teramplifikasi atau bahkan tidak ada daerah yang diamplifikasi. Optimalisasi ini menyangkut suhu denaturasi dan penempelan (annealing) DNA dalam mesin PCR (Butler, 2006).

Penggunaan teknologi DNA typing telah datang dan tercapai oleh FBI dari bank data DNA nasional yang disebut CODIS (Combined DNA Index System). Dua tujuan utama untuk operasi CODIS yang membantu peneliti dalam identifikasi tersangka kejahatan kekerasan, dan meningkatkan efektivitas laboratorium forensik dengan menyediakan perangkat lunak untuk melakukan kerja kasus DNA dan melakukan perhitungan statistic (Butler, 2006).

CODIS adalah database catatan hirarki identifikasi DNA. Catatan DNA CODIS berisi informasi terbatas untuk memungkinkan pencarian profil. Secara umum, catatan identifikasi berisi pengenal laboratorium, pengenal spesimen, karakteristik DNA, dan informasi untuk mengklasifikasikan dan meninjau catatan integritas DNA (Butler, 2006). Untuk benar-benar fungsional untuk membandingkan profil DNA, Laboratorium FBI harus menjadi jaringan terintegrasi antara lokal, negara bagian, dan laboratorium kriminal federal. Memungkinkan laboratorium kejahatan penegak hukum federal, negara bagian dan lokal untuk bertukar dan membandingkan profil DNA untuk menghubungkan kejahatan kekerasan seri dan untuk mengidentifikasi potensi tersangka dengan mencocokkan profil DNA dari bukti TKP dan profil pelaku (Butler, 2006).

Untuk tujuan menerapkan teknologi berbasis PCR untuk pengujian identitas manusia dan karenanya penggunaan bank data DNA nasional, penanda genetik polimorfik didefinisikan, teknik analisis yang kuat, dan studi populasi diperlukan. Short tandem repeats (STR) adalah bagian DNA yang pendek dan bersifat polimorfik yang paling informatif berdasarkan PCR untuk mencoba untuk mengindividualisasi bahan biologis. Lokus STR terdiri dari urutan tandem berulang (masing-masing dua sampai tujuh pasang basa panjangnya), sangat informatif, dan ketika diperkuat secara bersamaan dalam PCR multipleks, bisa sangat efektif untuk mengidentifikasi berbagai sampel forensik. Keputusan untuk memilih lokus STR sebagai penanda genetik untuk CODIS sangat jelas (Butler, 2006).

Laboratorium FBI bersama komunitas ilmuan forensik untuk membangun inti lokus STR untuk indeks DNA nasional. Pada tanggal 9 April 1996, pertemuan organisasi, didukung oleh program Laboratorium FBI CODIS, diadakan untuk mendirikan sebuah agenda proyek penelitian untuk memvalidasi aplikasi forensik dari sejumlah lokus STR untuk mengetik bukti biologis DNA (Butler, 2006). Tujuan dari pertemuan ini adalah untuk mengidentifikasi calon lokus STR yang dapat dianalisis dengan deteksi fluorescent, untuk menentukan tugas penelitian laboratorium untuk berpartisipasi dan melaporkan hasil pada selang waktu tertentu.

Tujuan antisipasi adalah untuk menguji, mengevaluasi, dan / atau mengoptimalkan PCR dan kondisi mengetik untuk komersial yang tersedia kit STR yang berisi kandidat tanggal lokus STR untuk semua laboratorium dalam mengevaluasi protokol, setelah kondisi ketikan yang diinginkan didirikan untuk membangun basis data kependudukan yang relevan, melakukan pencemaran lingkungan dan studi evaluasi kerja kasus. Lokus STR yang dievaluasi adalah CSF1PO, F13AO1, F13B, FES / FPS, FGA, TH01, LPL, TPOX, VWA, D3S1358, D5S818, D7S820, D8S1179, D13S317, D16S359, D18S51, dan D21S11 (Butler, 2006).

Pada pertemuan proyek STR 13-14 November 1997 lokus inti untuk sistem nasional disepakati oleh laboratorium 
yang berpartisipasi. Untuk mengambil keuntungan penuh dari kekuatan ketikan STR dan untuk memastikan kompatibilitas untuk pencarian profil DNA, semua peserta sepakat bahwa mengetik semua 13 lokus STR dapat di praktekkan ketika menganalisis kasus (Butler, 2006).

\subsection{Analisis Polymerase Chain Reaction (PCR)}

Polymerase chain reaction (PCR) digunakan untuk membuat jutaan kopi DNA dari sampel biologis. Amplifikasi DNA dengan menggunakan PCR menyebabkan analisis DNA pada sampel biologis hanya membutuhkan sedikit sampel dan dapat diperoleh dari sampel yang halus seperti rambut. Kemampuan PCR untuk mengamplifikasi sejumlah kecil DNA memungkinkan untuk menganalisa sampel yang sudah terdegradasi sekalipun. Namun, tetap saja harus dicegah kontaminasi dengan materi biologis yang lain selama melakukan identifikasi, koleksi dan menyiapkan sampelnya. Tes DNA dilakukan dengan cara mengambil DNA dari kromosom sel tubuh (autosom) yang mengandung area STR (short tandem repeats), suatu area ini tidak memberi kode untuk melakukan sesuatu. STR inilah yang bersifat unik karena berbeda pada setiap orang.

Perbedaannya terletak pada urutan pasang basa yang dihasilkan dan urutan pengulangan STR. Pola STR ini diwariskan dari orang tua. Aplikasi teknik ini misalnya pada tes DNA untuk paternalitas (pembuktian anak kandung) yaitu tes DNA untuk membuktikan apakah seorang anak benar-benar adalah anak kandung dari sepasang suami istri. Cara memeriksa tes DNA dilakukan dengan cara mengambil STR dari anak. Selanjutnya, di laboratorium akan dianalisa urutan untaian STR ini apakah urutannya sama dengan seseorang yang dijadikan pola dari seorang anak. Urutan tidak hanya satusatunya karena pemeriksaan dilanjutkan dengan melihat nomor kromosom. Misalnya, hasil pemeriksaan seorang anak ditemukan bahwa pada kromosom nomor 3 memiliki urutan kode AGACT dengan pengulangan 2 kali (Butler, 2006).

\subsection{Pengertian Air Tanah}

Air tanah merupakan bagian air di alam yang terdapat di bawah permukaan tanah. Pembentukan air tanah mengikuti siklus peredaran air di bumi yang disebut daur hidrologi, yaitu proses alamiah yang berlangsung pada air di alam yang mengalami perpindahan tempat secara berurutan dan terus menerus (Kodoatie dan Robert, 2012).

\subsubsection{Karakteristik Akuifer Air Tanah}

$\begin{array}{ccc}\text { Air tanah } & \begin{array}{c}\text { merupakan bagian } \\ \text { dari }\end{array} \text { siklus } & \text { hidrologi yang }\end{array}$ berlangsung di alam, serta terdapat dalam batuan yang berada di bawah permukaan tanah meliputi keterdapatan, penyebaran dan pergerakan air tanah dengan penekanan pada hubungannya terhadap kondisi geologi suatu daerah (Danaryanto, dkk. 2005) Berdasarkan atas sikap batuan terhadap air, dikenal adanya beberapa karakteristik batuan sebagai berikut :

1. Akuifer (lapisan pembawa air) adalah lapisan batuan jenuh air di bawah permukaan tanah yang dapat menyimpan dan meneruskan air dalam jumlah yang cukup dan ekonomis misalnya pasir.

2. Akuiklud (lapisan batuan kedap air) adalah suatu lapisan batuan jenuh air yang mengandung air tetapi tidak mampu melepaskannya dalam jumlah berarti misalnya lempung.

3. Akuitard (lapisan batuan lambat air) adalah suatu lapisan batuan yang sedikit lulus air dan tidak mampu melepaskan air dalam arah mendatar, tetapi mampu melepaskan air cukup berarti kea 
rah vertikal, misalnya lempung pasiran.

4. Akuiflug (lapisan kedap air) adalah suatu lapisan batuan kedap air yang tidak mampu mengandung dan meneruskan air, misalnya granit.

Menurut Undang-undang Nomor 11 Tahun 1974 tentang Pengairan, cekungan air tanah adalah suatu wilayah yang dibatasi oleh batas hidrogeologis, tempat semua kejadian hidrogeologis seperti proses pengimbuhan, pengaliran, dan pelepasan air tanah berlangsung.

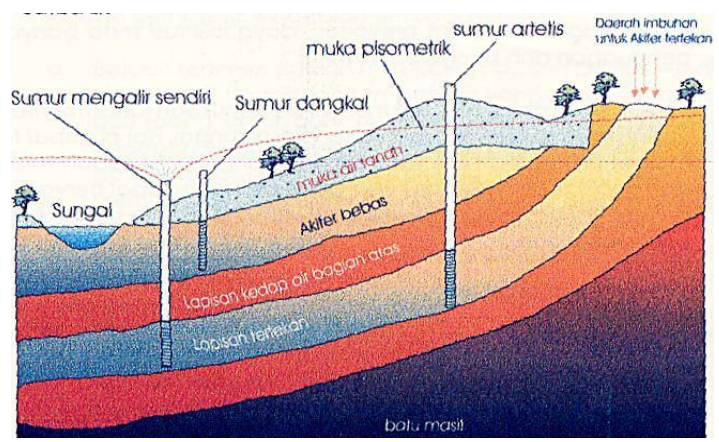

Gambar 5. Kedudukan Tipe Akuifer (Kodoatie, 2012)

Tipe akuifer digolongkan menjadi tiga (Kodoatie, 2012), yaitu :

1. Akuifer bebas (unconfined aquifer), merupakan akuifer jenuh air dimana lapisan pembatasnya hanya pada bagian bawahnya dan tidak ada pembatas di lapisan atasnya (batas di lapisan atas berupa muka air tanah).

2. Akuifer tertekan (confined aquifer), adalah akuifer yang batas lapisan atas dan lapisan bawah adalah formasi tidak tembus air, muka air akan muncul diatas formasi tertekan bawah. Akuifer ini terisi penuh oleh air tanah sehingga pengeboran yang menembus akuifer ini akan menyebabkan naiknya muka air tanah di dalam sumur bor yang melebihi kedudukan semula.

3. Akuifer semi tertekan (leaky aquifer), merupakan akuifer jenuh air yang dibatasi oleh lapisan atas berupa akuitard dan lapisan bawahnya merupakan akuiklud. Akuifer semi-tertekan atau aquifer bocor adalah akuifer jenuh yang sempurna, pada bagian atas dibatasi oleh lapisan semi-lulus air dan bagian bawah merupakan lapisan lulus air ataupun semi-lulus air.

\subsubsection{Gerakan Air Tanah}

Perbedaan potensi kelembaban total dan kemiringan antara dua lokasi dalam lapisan tanah dapat menyebabkan gerakan air dalam tanah. Air bergerak dari tempat dengan potensi kelembaban tinggi ke tempat dengan potensi kelembaban yang lebih rendah. Keseimbangan hidrologi dapat terjadi apabila tenaga penggerak air sebanding dengan jumlah tenaga gravitasi potensial dan tenaga hisap potensial, sehingga semakin tinggi kedudukan permukaan air tanah maka tenaga hisap potensial menjadi semakin kecil (Asdak, 2010). Hal ini berarti bahwa semakin besar tenaga hisap/ pemompaan, air tanah menjadi semakin kering. Ketika permukaan air tanah menurun sebagai akibat kegiatan pengambilan air tanah maka akan terbentuk cekungan permukaan air tanah.

\subsubsection{Kualitas Air Tanah}

Berdasarkan uraian di atas dapat diketahui bahwa pemanfaatan air tanah maupun air permukaan menjadi sesuatu yang sangat penting. Berkaitan dengan hal tersebut maka agar air dapat dimanfaatkan secara berkelanjutan dengan tingkat mutu yang diinginkan, salah satu langkah yang dilakukan adalah dengan pemantauan dan intepretasi data kualitas air. Pemantauan kualitas air mencakup kualitas fisika, kimia dan biologi. Kualitas air yaitu sifat air dan 
kandungan mahluk hidup, zat, energi, atau komponen lain di dalam air. Kualitas air dinyatakan dengan beberapa parameter, seperti parameter fisika yaitu suhu, kekeruhan, padatan terlarut, dan sebagainya, parameter kimia yaitu $\mathrm{pH}$, oksigen terlarut, $\mathrm{BOD}$, kadar logam, dan sebagainya dan parameter biologi yaitu keberadaan plankton dan bakteri (Effendi, 2003).

Apabila hasil pemantauan kualitas air tidak sesuai dengan hakekat seperti di atas maka air dapat dikatakan tercemar. Pencemaran air adalah masuk atau dimasukkannya makhluk hidup, zat, energi dan atau komponen lain ke dalam air oleh kegiatan manusia sehingga kualitasnya turun sampai ke tingkat tertentu yang menyebabkan air tidak berfungsi sesuai dengan peruntukaannya. Pencemaran air diakibatkan oleh masuknya bahan pencemar berupa gas, bahan terlarut, maupun partikulat yang menyebabkan air menjadi tidak lagi sesuai dengan kondisi alamiahnya. Bahan pencemar yang memasuki badan perairan bisa masuk dengan berbagai cara antara lain melalui tanah, atmosfer, limbah domestik, limbah industri dan lain sebagainya (Effendi, 2003).

Pencemaran bisa terjadi pada air permukaan (surface water) dan air tanah (groundwater). Kebanyakan pencemaran air tanah disebabkan oleh bahan pencemar yang bersifat cairan misalnya limbah industri. Ketepatan pengecekan kualitas air untuk menentukan tercemar atau tidaknya bisa dilakukan dengan pemeriksaan secara laboratorium. Untuk mengetahui apakah suatu air terpolusi atau tidak, diperlukan pengujian untuk menentukan sifat-sifat air sehingga dapat diketahui apakah terjadi penyimpangan dari batasan-batasan polusi air. Sifat-sifat air yang umum diuji dan dapat digunakan untuk menentukan tingkat polusi air misalnya : nilai $\mathrm{pH}$, keasaman dan alkalinitas, suhu, warna, bau dan rasa, jumlah padatan, nilai BOD/COD, pencemaran mikroorganisme patogen, kandungan minyak, dan kandungan logam berat (Purwanto, 2015).

\subsubsection{Parameter Kualitas Air Tanah}

1. Suhu

Suhu dipengaruhi oleh musim, letak lintang (latitude), ketinggian tempat dari permukaan laut (altitude). Suhu memberi efek pada konsentrasi oksigen terlarut dan berpengaruh pada aktifitas bakteri dan kimia toksik di dalam air (Effendi, 2003). Suhu air juga mempengaruhi aktivitas mikroorganisme dalam penguraian bahan bahan organik, dimana semakin tinggi suhu maka aktivitas mikroorganisme semakin meningkat yang menyebabkan pengambilan atau pemanfaatan oksigen terlarut dalam air semakin meningkat.

\section{Zat Padat Terlarut (Total Disolve Solid /TDS)}

Zat padat terlarut adalah jumlah zat padat yang terlarut dalam air/ semua zat yang tertinggal setelah diuapkan pada suhu $103-105^{\circ} \mathrm{C}$. Padatan terlarut meliputi garam garam anorganik dan sejumlah kecil zat organik serta gas. Berdasarkan kriteria baku mutu air kelas I, yaitu air yang dapat digunakan sebagai air baku untuk diolah sebagai air minum dan keperluan rumah tangga, batas maksimum yang diperbolehkan adalah $1000 \mathrm{mg} / \mathrm{l}$ (Effendi, 2003).

Menurut Badan Geologi, Pusat Sumber Air Tanah dan Geologi Lingkungan (2014), disebutkan batasan nilai TDS air tanah digolongkan seperti Tabel 1 . 
Tabel 1. Klasifikasi Air Tanah Berdasarkan Total Disolve Solid/TDS

\begin{tabular}{|c|c|c|}
\hline No & $\begin{array}{l}\text { TDS (Miligram/ } \\
\text { liter) }\end{array}$ & $\begin{array}{c}\text { Tingkat kerusakan air } \\
\text { tanah }\end{array}$ \\
\hline 1 & $<1000$ & Aman \\
\hline 2 & $1000-10.000$ & Rawan (payau) \\
\hline 3 & $>10.000$ & Kritis (asin) \\
\hline
\end{tabular}

\section{3. $\mathrm{Cl}$ (Klorida)}

Ion khlorida tidak secara langsung menyebabkan toksik, tetapi kelebihan garam ini paling banyak terdapat sebagai garam garam klorida yang dapat menyebabkan penurunan kualitas air yang disebabkan oleh besarnya salinitas. Batas maksimum ion khlorida yang dianjurkan $200 \mathrm{mg} / \mathrm{l}$, sedangkan batas maksimum yang diperbolehkan adalah $500 \mathrm{mg} / \mathrm{l}$ (Kodoatie, 2012).

Konsentrasi khlorida $\left(\mathrm{C}^{-} 1\right)$ dapat mempengaruhi kualitas air tanah dan juga menentukan system klasifikasi air tanah. Berdasarkan tipe penentuan sistem klasifikasi kimia air tanah dibedakan menjadi enam divisi seperti ditunjukkan pada Tabel. 2.

Tabel 2. Pembagian Kualitas Air Tanah Berdasarkan Konsentrasi Cl

\begin{tabular}{|c|c|c|c|}
\hline No & Tipe Air Tanah & Kode & $\begin{array}{l}\text { Banyaknya } \\
\mathrm{Cl}^{-} \text {(mg/l) }\end{array}$ \\
\hline 1 & $\begin{array}{l}\text { Air bersih/minum } \\
\text { (fresh) }\end{array}$ & $\mathrm{F}$ & $\leq 200$ \\
\hline 2 & $\begin{array}{l}\text { Air bersih-payau } \\
\text { (fresh-brackish) }\end{array}$ & $\mathrm{Fb}$ & $200-500$ \\
\hline 3 & Air Payau (brackish) & $\mathrm{B}$ & $500-1000$ \\
\hline 4 & $\begin{array}{l}\text { Air payau-garam } \\
\text { (Brackish-salt) }\end{array}$ & Bs & $1000-10000$ \\
\hline 5 & Air garam (salt) & S & $10000-2 \times 10^{4}$ \\
\hline 6 & $\begin{array}{l}\text { Air kadar garam } \\
\text { tinggi (hipersaline) }\end{array}$ & $\mathrm{H}$ & $\geq 2 \times 10^{4}$ \\
\hline
\end{tabular}

\section{DO (Oksigen terlarut)}

Tingkat kelarutan oksigen yang ada di dalam lingkungan perairan merupakan faktor yang sangat penting dalam kualitas air. Oksigen terlarut dalam air bersumber dari difusi oksigen atmosfir dan hasil foto sintesis tumbuhan dalam air. Sedangkan pengurangan oksigen terlarut disebabkan karena digunakan respirasi hewan dan tumbuhan.

Menurut Achmad, 2004, daya larut oksigen dalam air dipengaruhi suhu perairan, ketinggian tempat dan tingkat turbulasi. Semakin tinggi suhu perairan maka daya larut oksigen semakin rendah. Begitu juga semakin tinggi ketinggian tempat maka daya larut oksigen juga semakin rendah. Perairan yang turbulansinya tinggi akibat adanya arus angin dan gelombang maka daya larut oksigen semakin tinggi. Batas maksimum dari pada DO yang diperbolehkan adalah $\geq 6$ (Achmad, 2004).

\section{Tingkat Keasaman ( $\mathrm{pH})$}

Keasaman air pada umumnya disebabkan karena adanya gas karbon dioksida $\left(\mathrm{CO}_{2}\right)$ yang larut dalam air dan menjadi asam karbonat $\mathrm{H}_{2} \mathrm{CO}_{3}$. Untuk menyatakan keasaman dan kebasaan air yaitu dengan mengukur pH air. Syarat $\mathrm{pH}$ untuk keperluan air minum 6,0 - 9,0. Nilai $\mathrm{pH}$ suatu perairan menicirikan keseimbangan antara asam dan basa dalam air dan merupakan pengukuran konsentasi ion hydrogen dalam larutan. Adanya karbonan hidroksida dan bikarbonat menaikkan kebasaan air. Sementara adanya asam mineral bebas dan asam karbonat menaikkan keasaman. $\mathrm{pH}$ air dapat mempengaruhi jumlah dan susunan zat dalam lingkungan perairan dan mempengaruhi tersedianya harahara serta toksitas dari unsur-unsur renik (Achmad, 2004).

Mengingat nilai $\mathrm{pH}$ ditentukan oleh interaksi berbagai zat dalam air, termasuk zat- zat yang secara kimia maupun biokimia tidak stabil, maka penentuan $\mathrm{pH}$ harus seketika setelah contoh diambil dan tidak dapat diawetkan (Achmad, 2004). Ukuran pH suatu perairan dapat digunakan sebagai indikasi suatu pencemaran khususnya pencemaran bahan organik. Pemecahan bahan organik oleh mikroorganisme akan menghasilkan 
karbon dioksida. Peningkatan karbon dioksida akan mengakibatkan penurunan nilai $\mathrm{pH}$ jika system buffer karbonat di perairan rendah. Perairan yang mempunyai $\mathrm{pH}$ rendah akan dapat meningkatkan toksisitas beberapa persenyawaan gas-gas tertentu dalam air seperti amoniak.

\section{Daya Hantar Listrik (DHL)}

Daya Hantar Listrik (DHL) menunjukkan kemampuan air untuk menghantarkan listrik. Konduktivitas air tergantung dari konsentrasi ion klorida, suhu air dan zat padat terlarut. Oleh karena itu kenaikan padatan terlarut akan mempengaruhi kenaikan DHL. Semakin tinggi temperatur dan ion klorida maka nilai DHLnya juga semakin tinggi dan sebaliknya semakin rendah nilai DHL maka suhu maupun ion klorida akan rendah pula. Menurut Achmad, 2004 batasan nilai DHL air tanah adalah digolongkan seperti Tabel 3. Berdasarkan Daya Hantar Listrik (Achmad, 2004)

Tabel 3. Klasifikasi Air Tanah

\begin{tabular}{clc}
\hline No & DHL (mikro Mhos/cm) & Jenis air \\
\hline 1 & $0-1000$ & Air tawar \\
\hline 2 & $1000-2000$ & Air payau \\
\hline 3 & $2000-10000$ & Air asin \\
\hline 4 & $>$ & Sangat asin \\
\hline
\end{tabular}

\section{METODE PENELITIAN}

Jenis penelitian yang digunakan adalah penelitian eksperimental yaitu, penelitian diarahkan untuk mengamati dan menjelaskan suatu keadaan atau situasi yang terjadi (sebab dan akibat) dalam tingkatan waktu tertentu dan tidak dapat dikendalikan oleh peneliti (Jogiyanto, 2008). Penelitian ini bertujuan untuk mengidentifikasi DNA dari bercak sperma pada kain yang di rendam pada air tawar berdasarkan perbedaan waktu dengan metode STR-CODIS (Short Tandem Repeat Combined DNA Index System) untuk kepentingan forensik.

\begin{abstract}
Rancangan penelitian yang digunakan adalah rancangan eksperimental time series, yaitu populasi yang sama diamati dalam periode tertentu secara longitudinal ke depan (Sugiyono, 2003). Rancangan ini menggunakan pendekatan eksperimen dengan adanya perbedaan waktu pengambilan sampel bercak sperma pada hari ke-1, hari ke-3 dan hari ke-7. Pada setiap waktu (hari) dilakukan pengambilan sampel sebanyak tiga kali $(3 \mathrm{x})$ pengulangan atau replikasi sampel untuk menguji keakurasian sampel.
\end{abstract}

\section{HASIL DAN PEMBAHASAN}

Tabel.4 Hasil rerata DNA

\begin{tabular}{|c|c|c|c|}
\hline $\begin{array}{c}\text { Air } \\
\text { tawar }\end{array}$ & $\begin{array}{c}\text { Kadar DNA } \\
(\mathrm{ng} / \mu \mathrm{l}) \\
(\lambda 260 \times \\
\text { pengenceran } \times 50 \\
\mathrm{ng} / \mu \mathrm{l})\end{array}$ & $\begin{array}{c}\text { Rerata } \\
\text { kadar } \\
\text { DNA }\end{array}$ & $\begin{array}{c}\text { Kemur } \\
\text { nian } \\
\text { DNA } \\
(\lambda 260: \\
\lambda 280)\end{array}$ \\
\hline \multirow{6}{*}{1 hari. } & 98,66 & \multirow{6}{*}{$\begin{array}{c}40.43 \pm \\
29.69\end{array}$} & 1,59 \\
\hline & 26,38 & & 1,65 \\
\hline & 31,60 & & 2,04 \\
\hline & 18,97 & & 1,53 \\
\hline & 23,87 & & 1,66 \\
\hline & 43,08 & & 1,81 \\
\hline \multirow{6}{*}{3 hari. } & 241,10 & \multirow{6}{*}{$\begin{array}{c}139.66 \\
\pm \\
65.43\end{array}$} & 1,94 \\
\hline & 159,56 & & 1,70 \\
\hline & 176,93 & & 1,80 \\
\hline & 111,73 & & 1,81 \\
\hline & 71,90 & & 1,81 \\
\hline & 76,76 & & 1,77 \\
\hline \multirow{6}{*}{7 hari } & 246,34 & \multirow{6}{*}{$\begin{array}{c}151.38 \\
\pm \\
49.31\end{array}$} & 2,28 \\
\hline & 163,92 & & 1,94 \\
\hline & 118,76 & & 1,90 \\
\hline & 132,15 & & 1,93 \\
\hline & 123,44 & & 1,90 \\
\hline & 123,69 & & 1,89 \\
\hline
\end{tabular}

Hasil rerata kadar DNA menunjukkan kenaikan yang signifikan setiap waktunya. Hal ini dipengaruhi oleh sifat kain katun yang dapat menyerap cairan meskipun dalam keadaan basah.

Dalam amplifikasi Ukuran DNA produk PCR (bp) untuk lokus D13S317 : 169-201 bp. Gambar 6 dibawah ini menunjukkan hasil amplifikasi PCR lokus D13S317 terhadap sampel bercak sperma yang di rendam pada air tawar dari hari ke-1, ke-3, dan ke-7 terlihat pita dan band DNA. Dari gambar 6 terlihat ukuran pita DNA tiap-tiap sampel berbeda. 


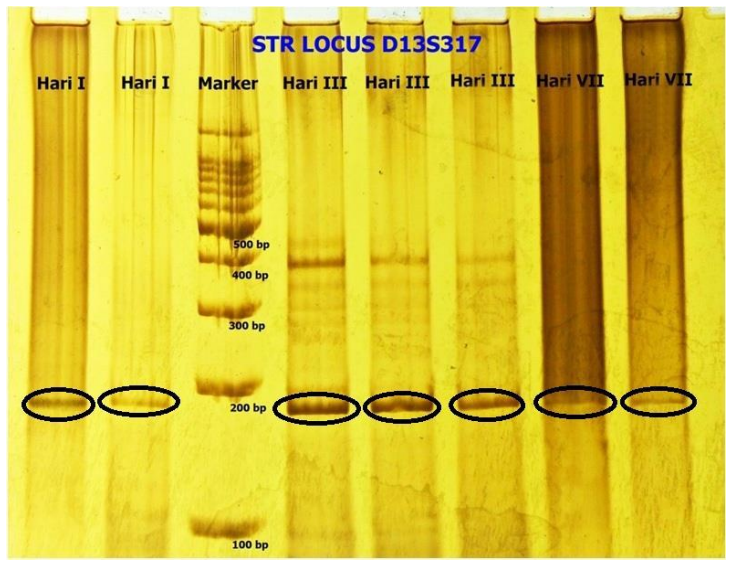

Gambar 6. Hasil PCR lokus D13S317

Ukuran DNA produk PCR (bp) untuk lokus D21S11 : 203-259 bp. Gambar 5.3 diatas menunjukkan hasil amplifikasi PCR lokus D21S11 terhadap sampel bercak sperma yang di rendam pada air tawar dari hari ke-1, ke-3, dan ke-7 terlihat pita dan band DNA. Dari gambar 5.3 terlihat ukuran pita DNA tiap-tiap sampel berbeda pada lokus yang sama, yaitu lokus D21S11.

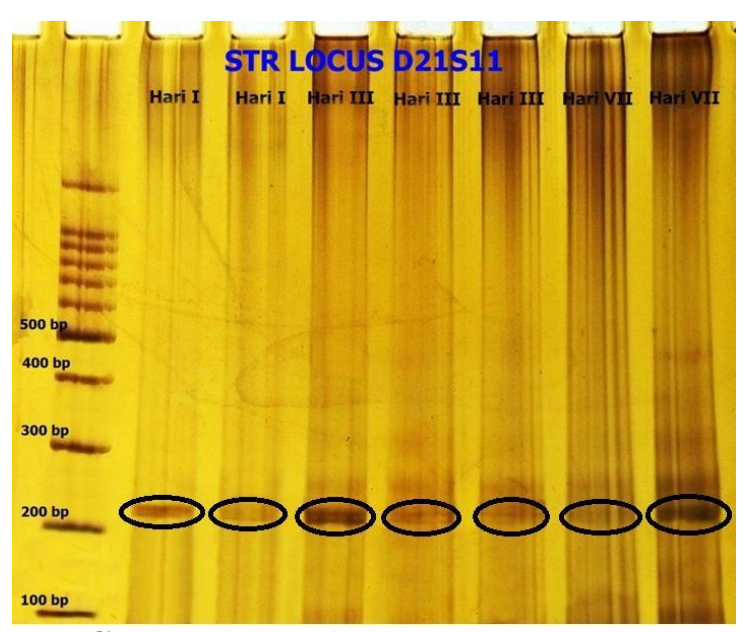

Gambar 7. Hasil PCR lokus D21S11

\section{KESIMPULAN DAN SARAN}

Kesimpulan yang didapat pada penelitian ini bahwa isolasi DNA bercak sperma pada kain katun yang di rendam selama 1, 3, dan 7 hari memiliki nilai kadar dan kemurnian yang berbeda-beda. Hasil yang didapatkan pada penelitian ini tentang kadar dan kemurnian DNA mengalami peningkatan yang signifikan.
Hal ini terjadi karena media dari bercak sperma adalah kain katun. Kain katun memiliki sifat yang kuat dalam keadaan basah bertambah $25 \%$, dapat menyerap air yang tinggi (higroskopis). Semakin lama sampel bercak sperma pada kain katun berada semakin pula komponen- komponen dan termasuk DNA sampel bisa menyerap kedalam serat kain katun.

Saran yang dapat diberikan adalah Variasi jenis sampel sangat diperlukan dalam penelitian selanjutnya. Untuk masalah media di anjurkan untuk lebih memilih media baru yang belum pernah di teliti yang berhubungan dengan pengaruh kualitas DNA.

\section{UCAPAN TERIMA KASIH}

1. Dr. Puspa Wardhani, dr.,Sp.PK Selaku pembimbing yang telah bnyak memberikan pengarahan, bimbingan, dan tambahan ilmu serta wawasannya.

2. Dr. Ahmad Yudianto, dr., Sp.F. M.Kes. SH. Selaku Ketua Program Studi Magister Ilmu Forensik, Universitas Airlangga serta pembimbing yang telah memberikan pengarahan, tambahan ilmu dan wawasannya.

3. Prof. Dr. Med. H. M. Soekry Erfan K. dr. $\operatorname{SpF}(\mathrm{K})$. DFM. Selaku Kepala Laboratorium Human Genetic, Institute of Tropical Disease, Universitas Airlangga, yang telah memberikan kesempatan kepada saya untuk melaksanakan penelitian di laboratorium Human Genetic.

\section{DAFTAR PUSTAKA}

Achmad, Rukaesih. 2004. Kimia Lingkungan. Yokyakarta: Andi .

Adnan. 2006. Reproduksi dan Embriologi. Makassar: Badan Penerbit UNM.

Asdak, Chay. (2010). Hidrologi dan Pengelolaan Daerah Aliran Air Sungai: Edisi Revisi Kelima. Yogyakarta: Gadjah Mada University Press Yogyakarta. 
Butler JM, 2006. Genetics and Genomics of Core Short Tandem Repeat Loci Used in Human Indentity Testing. J Forensic Sci. Vol 51, No 2, doi : 10.1111/j.15564029.2006.00046.x : 253-265

Campbell NA, Reece, Mitchell. 2004. Biology Concept and Connection. Ed.5. San Fransisco: Benjamin Cummings.

Danaryanto, H. (2005), Air Tanah di Indonesia dan Pengelolaannya. Jakarta: Departemen ESDM.

Effendi, H. 2003. Telaah Kualitas Air bagi Pengelolaan Sumber Daya dan Lingkungan Perairan. Cetakan Kelima. Yogjakarta : Kanisius.

Jogiyanto. 2008. Metodelogi Penelitian Informasi. C. V Andi Offset. Yogyakarta.

Kodoatie, Robert J. 2012. Tata Ruang Air Tanah. Penerbit Andi, Yogyakarta. Lewis, R. 2003. Human genetics: Concepts and applications. The McGraw-Hills Company, Inc., Boston: xviii $+454 \mathrm{hlm}$.

Raven, P.H. \& G.B. Johnson. 2002. Biology. 6th ed. McGraw-Hill Companies, Inc., New York: xxiv +1238 hlm.

Rena Yulia, 2010, Viktimologi: Perlindungan Hukum Terhadap Korban Kejahatan, Yogyakarta, Penerbit Graha Ilmu,

Singh A, Agarwal A. The role of sperm chromatin integrity and DNA damage on male infertility. The Open Reproductive Science Journal. 2011;3:65-71.

Haryani, F. M. Ghazali, dan R. Son. 2007. Meat Molecular Detection: Sensitivity of Polymerase Chain ReactionRestriction Fragment Length Polymorphism in Species Differentiation of Meat From Animal Origin. ASEAN Food Journal 14(1):5159.

Sugiyono. 2003. Metodelogi Penelitian Pendidikan. Bandung : Alfabeta.

Suryo. 2005. Genetika Manusia. Yogyakarta: Gadjah Mada University Press.

Toha, A.H. 2001. DNA Keanekaragaman, Ekspresi, Teknologi dan Efek Pemanfaatannya. Bandung: Penerbit Alfabeta. Ong S.B., M.I. Zuraini, M. G.
Jurin, Y. H. Cheah, R. Tunung, L. C. Chai, Y. 